\title{
SOVYET TOPLUMUNDA SPORUN ROLÜ
}

\author{
Metin KILIÇ* \\ Mahir ASLAN**
}

\begin{abstract}
Özet
Sporun son yüzyıllık serüveninde devlet hayatında ve ülke imajının oluşturulmasında önemli bir kurumsallık sergilediği göz ardı edilemez. Bireysel bir fenomen olarak sporun değerlendirilmesinden ziyade, toplumsal bir olgu olarak spor, sosyo-kültürel yapının şekillenmesinde etkilidir. $\mathrm{Bu}$ anlamda birçok modern toplumda, bu dönemde, spor kurumundan devlet politikası olarak istifade edebilmek hedeflenmiştir. Kuşkusuz bu süreçte Sovyet toplumlarında spora yüklenen sosyolojik anlam toplumsal değişim adına göz ardı edilmeyecek bir öneme sahiptir.

Çalışmada Sovyet toplumunda spor kültürünün kitlesel olarak geliştirilmesinde ve uluslararası arenada var olmada, spora yüklenen anlam üç aşamada incelenmiş, Spartakiada ve Moskova Olimpiyatları sosyo-politik olarak çözümlenmeye çalışılmıştır.
\end{abstract}

Anahtar Kelimeler: Spor Sosyolojisi, Spor Politikasl, Spor Tarihi, SSCB, Toplumsal Yapı

\section{The Role of Sports in the Soviet Society}

\begin{abstract}
It can not be overlooked that sports, in its journey in the last century, exhibits an important institutionalism in the creation of country's image and the state of life. Sport as a social phenomenon, is effective in shaping the socio-cultural structure rather than being evaluated as an individual phenomenon. In this sense, in many of the modern societies, in this period, the sports institutions were aimed to be able to benefit

\footnotetext{
* Yrd. Doç. Dr., Düzce Üniversitesi Fen Edebiyat Fakültesi Sosyoloji Bölümü

** Mimar Sinan Güzel Sanatlar Üniversitesi Sosyal Bilimler Enstitüsü Doktora Öğrencisi
} 
from state policy. Undoubtedly, within this period, the sociological meaning assigned to sports in Soviet societies has an importance that cannot be ignored in the name of change.

In the study; the meaning assigned to sports has been examined in three stages both in the collective development of sports culture and its existence in the international arena in Soviet society; in addition, Spartakiada and Moscow Olympics have been analyzed socio-politically.

\section{Structure}

Keywords: Sociology of Sport, Sport Policy, Sport History, USSR, Social

\section{Giriş}

Tüm insanlık tarihi boyunca nesilden nesile aktarılan teknik ve fiziki faaliyetlerin genel manada bir ürünü olan spor, bireysel bir eylemin sonucunda toplumsal bir olguya dönüşmüştür. Spor ilk önceleri sürekli fiziki aktivitenin artışıyla ve daha yüksek başarılara ulaşma arzusuyla birlikte, temelde yarışma ruhunda insanların ilgisini çeken bir oyun formunda var olmuştur. $\mathrm{Bu}$ sebepledir ki spor, sadece insan fiziki olgunluğunun amacına boyun eğerken suni bir üretim ilişkisini içinde barındırmadan aynı zamanda bir kültür sahasına dönüşmüştür. ${ }^{1}$ Bununla birlikte spor sosyo-kültürel bir vaka olarak içerisinde birçok soru ve tartışmayı da barındırmaktadır. Belirtmek gerekir ki spor sadece bağımsız bireyin hayatında önemli rol oynamıyor. Muayyen toplumsal birliklerde olduğu gibi aynı şekilde devlet hayatında da, ülke imajının oluşturulması ve sağlamlaştırılmasında da bir o kadar mühim yere sahiptir. ${ }^{2}$

Birçok sahada modern Rus toplumunun gelişimi evvelki tarihi gelişimin mirası ile vücut bulmaktayken, Rus sporunun bugünkü durumu da aynı şekilde Sovyet döneminde ve temelde onun eğilim ve niteliklerinde şekillenmiştir. 20. Yüzyılda spor toplum hayatında ciddi etki gösteren kitlesel bir fenomene dönüşürken, gerek içeride gerekse uluslararası boyutta milletlerin iletişimini sağlayan istisnai soyso-kültürel bir çizgiye de ulaşmıştır. Sonuç olarak dünyanın birçok ülkesinde devlet politikasının eğilimlerinde öncelikli yeri

\footnotetext{
${ }^{1}$ T. Niva, "Funktsiya Sporta v Sovremennom Obşestve", Sport i Obraz Jizni, Sbornik Statey, Moskva, 1979, s. 125

2 Sazanova Yu.A," Konseptsiya Sporta Kak Politika i Yiyo Realizatsiya Na Stranah SMI," Gumanitarnie Nauçnie İsledovaniya, 2004, No:2, s. 1
} 
almış ve en yüksek seviyede devlet idareleri tarafından spordan istifade edilmiştir. $^{3}$

$\mathrm{Bu}$ manada, spor ve fizik kültürünün gelişimine gösterilen ilgi devlet politikasının en önemli toplumsal bileşenidir. Spor yapmak milli şuur, hoş görü, yardımlaşma vb. niteliklerin gelişmesine yardımcı olduğu gibi kişinin sosyalleşme sürecini de olumlu yönde etkilemektedir. Karmaşık ve aynı zamanda çok taraflı bir sosyal fenomen olarak kendi bünyesinde müstakil alt sistemleri de barındıran sporun, bu alt sistemlerinin gelişmesinde kendi değerleri, işlevi ve yasaları mevcuttur. Makro düzeyde toplumsal bir alt sistem olan spor, göreceli özgünlüğe sahipken toplumun ve devletin diğer alt sistemlerinden de izole değildir. İnsan hayatının tüm diğer tarafları olan politika, sağlık, ekonomi, kültür, eğitim, aile, hukuk vb. ile de sıkı ilişki içerisindedir. Spor toplumsal bir okul olarak toplumun temel yaşam faaliyet alanlarında etki gösterirken, her şeyden önce kişinin toplumsal hazzı ve fiziki sağlığını sürdürerek bireyin farklı ihtiyaçlarını tatmin ederken toplumsal ilişkileri, iş hayatını, sosyal durumu, modayı, etik değerleri ve insanların hayat tarzlarını da şekillendirmektedir. Spor fenomeni bu yönüyle güçlü bir sosyalleştirme gücüne sahiptir. ${ }^{4}$

\section{Kültür Devriminde Sporun Rolü}

Sovyet Rusya'sında sporun ve beden eğitiminin öncü sosyal rolünün bilincine 1920'li yıllarda "Beden eğitimi kültür devriminin özüdür" sözü telaffuz edilmeye başlandığında varılmıştır. Sağlıklı insanın yetiştirilmesi, Rusların sağlıklı yaşam tarzlarının şekillendirilmesi bugünkü temin edilmesi gereken en önemli devlet politikalarından biridir. $\mathrm{Bu}$ meselenin temini ise beden eğitimi ve spor olmadan mümkün değildir. Sporla meşgul olmak, spor yapmak her geçen gün toplumda ve muayyen guruplar arasında kişinin kimliğinin oluşmasında statü bazında da rol oynamaktadır. Gerek Sovyet devletinin iç politik ve toplumsal hayatındaki değişim gerekse 1920-1930'lu yıllarda yurt dışındaki meydana gelmiş değişimler, doğrudan beden eğitimi ve spora olan alakaya ve onun öğrenimine ciddi etki etmiştir. Spor "yeni insanın"

3 Sergey Valeryeviç Buton, Razvitiye Sovetskovo Futbola (1921-1941), Yayınlanmamış Yüksek Lisans Tezi, Krosnoyarsk, 2007, s. 3

4 T. Kalomnikova, A. Varonin, "Sotsialnaya Rol Sporta v Razvitii Obşestva i Sotsializatsii Liçnosti,” Uspehi Savromennovo Estestvaznaniya, No:10, 2013, s. 206 
eğitimi sistemine dâhil edilirken gençlerinde askeri-politik hazırlıklarının da en önemli aracı olarak görülmeye başlamıştır. ${ }^{5}$

Sporun devlet hayatında önemli bir rol oynamaya başlaması Marks ve Engels'in dikkatlerini de üzerine çekmesine sebep olmuştur. Bu durumları ile onlar sporu politik mücadele prizmasından inceleyen ilklerden olmuşlardır. Onların ideolojik bakış açılarına göre spor meziyetine göre değerlendirilmiştir. Sporun yeni şekil almasıyla birlikte, karakteristik olarak spor ve kitlesel beden eğitiminin değişimi ile Marksist cephede de spora olan ilgi ve yaklaşımda değişiyordu. Sporun her gelişmiş devletin hayatında önemli bir halka olarak anlaşılması Marksist görüşte hemen yer bulamadı. Muayyen bir zaman dilimi geçtikten sonra, her şeyden önce bu sahada Marksist teorinin gelişmesi sonucunda, spor kitlelerin etkilenmesinde en önemli politik enstrümanlardan biri olarak algılanmaya başladı. Hali hazırdaki bu yaklaşım 1920-1930'lu yıllarda kendi nihai pratik tekâmülünü Sovyet coğrafyasında tamamladı. ${ }^{6}$

Belirtmek gerekir ki, toplum ve insan hayatında beden eğitimi ve sporun yeri Marksistlere göre, elbette ki kendi geleneksel teorik değerlerine göre, beden eğitiminin görev ve hedefi işçi sınıfının fiziki sağlamlığ1 ve moralman sağlam olmasıydı. Çünkü işçi sınıfını kendi parlak geleceği için onları ezici mücadeleler bekliyordu. Komünist fikirlerin oturması, sosyalist devrimin hedeflerine ulaşılması, onların her yerde yayılması, aynı şekilde sosyalizmin savunucuları ve yeni nesillerin yetiştirilmesinde, Marksistlere göre; beden eğitimi ve spor paha biçilemez bir rol oynayabilirdi. Tüm insanlığın aydınlık geleceği için yenilmez ruhla savaşacak savaşçıların ve komünizmi inşa edecek yeni yetişen nesillerin yetiştirilmesinde kitlesel beden eğitimi hiç olmazsa kitlesel spor, hem pratik hem de propagandanın en iyi araçlarından biri olabilirdi. $^{7}$

Sovyet devletinin kurulması ile birlikte Dünya'nın kabul ettiği normlar çerçevesinde halkın fizik eğitiminin gelişmesine ve fiziki sportif faaliyetlerin

\footnotetext{
5 Pavel Viladimiroviç Salovyev, Fiziçeskaya Kultura i Sport v Sotsyokulturnom Razvitii Sibirskovo Goroda Tomska: 1920-1941, Yayınlanmamış Yüksek Lisans Tezi, 2007, s.3,4,5

${ }^{6}$ Artiom Nikolayeviç Filippov, Gasudarstvennaya Politika SSSR v Oblastı Fiziçeskoy Kulturı i Sporta: 1920-1930, Yayınlanmamış Yüksek Lisans Tezi, Yaroslavl, 2012, s. 35

${ }^{7}$ Artiom Nikolayeviç....a.g.t., s. 35-36
} 
sağlanmasına ciddi manada dikkat gösterilmiştir ${ }^{8}$. Yeteri kadar uzman ve tecrübeli yöneticinin yetişmemiş olmasından dolayı spora dair birçok yeni girişim Sovyet iktidarının kurulup yerleşmesiyle ancak başlayabilmiştir. ${ }^{9} 1919$ yılında Petersburg'da beden eğitimi ve spor alanında kadroların yetiştirilmesi için Halk Komiserleri Kurulu kararı ile P.F. Lesgaft adına beden eğitimi yüksekokulu ve bir y1l sonra Moskova'da devlet beden eğitiminin kurulması ile beden eğitimi ve spor alanının bilimsel idaresinin temelleri şekillenmeye başlamıştır. $\mathrm{Bu}$ dönemde beden eğitimi ve spor sahasındaki bilimsel ve metodik çalışmalar zorunlu eğitim disiplini olarak tüm ülkedeki teknik ve yüksekokulların kitap ve eğitim planlarına uygun olarak yerleşmeye başlamıştır. $^{10}$

Sovyetler Birliğinde spor ve beden eğitimi dallar arası devlet idaresi, SSCB beden eğitimi ve spor komitesi tarafından tesis olunmuştur. Aynı şekilde adı geçen komite gelecekteki ittifak cumhuriyetleri ile birlikte toplumun beden eğitiminin olgunlaştırılıp organize edilmesi, sporcuların hazırlanması ve kendisine ihdas olunan yönetim alanında birleşik devlet politikasının uygulanmasını komite kendi sorumluluk sahası içine almıştır. SSCB devlet spor komitesi spor ve beden eğitimi idaresini hayata geçirirken adet olduğu üzere birlik cumhuriyetleri ile birlikte işletmeleri, organizasyonları, eğitim kurumları ve diğer kurumları da yönetmiştir. $\mathrm{Bu}$ dönemde SSCB devlet spor komitesi doğrudan SSCB Halk Milletvekilleri Komitesi önünde sorumlu ve hesap verir durumdadır. ${ }^{11}$

Rusya'da 1917 yılında meydana gelen rejim değişikliği ile birlikte kurulan Sovyetler Birliği hızlı bir şekilde Çarlık Rusya'sından devraldı̆̆ 1 ülkede siyasi doktrin ve dünya görüşüne uygun olarak hızlı bir değişim yoluna gitmiştir. Sovyetler Birliği kuruluşunun ilk yıllarında kaçınılmaz olarak yoluna Çarlık kurum ve kadroları ile devam etmiştir. Aynı zamanda bu sürece paralel olarak da ideolojik prensiplerine çerçevesinde kendi kurum ve

8 Aleksandr Yuryeviç Bliznevskiy, Programmo-Tselevoe Upravlenie Razvitiem SferiFiziçeskoy Kulturı i Sporta v Prostranstve Krasnoyarskovo Kraya, Yayınlanmamış Doktora Tezi, 2015, Krasnoyarsk, s. 24

9 http://minsport.gov.ru/ İstoriya Razvitiya Fizkulturı i Sporta Sredi Selskovo Naseleniya v SSCB i Rassıskoy Federatsii.

${ }^{10}$ Aleksandr Yuryeviç Bliznevskiy, a.g.t., s. 24

${ }^{11}$ Ya.Yu. Ratuşnaya, Yu. İ. Mihaylov, "Organı Upravleniya Fiziçeskoy Kulturoy i Sportom v 1991-2007” (Regionalniy Aspekt), Vestnik KemGU, No: 3 (51), 2012, s. 97 
kadrolarını yetiştirmeye başlamıştır. Yeterli seviyeye ulaştığını düşündüğü noktada ve zamanla Sovyet sistemine dâhil olmayan ve bir şekilde dışında kalan kurum ve kadroları sırası geldikçe tasfiye etmiştir. Konumuz ile bağlı olarak şüphesiz ki Sovyetlerin Çarlıktan farklı olarak spora ve spor kurumlarına bakışı farklı idi. Çarlık Rusya'sında belirli bir zümrenin meşgul olabildiği ve dar bir çevreye sıkışmış olan spor Sovyetler için tamamen farklı bir işleve sahiptir. Bu bağlamda Sovyetler Birliğinde sporun gelişimi ve onun toplumu şekillendirmesindeki rolünü üç etap halinde inceleyebiliriz.

\section{Birinci Etap: Sporun Toplumsal Önemini Anlama (1917-1923)}

$\mathrm{Bu}$ dönem, beden eğitimi vasitasıyla ve ondan istifade edilerek tüm askeri eğitimle ilgili stratejik kararın şekillendirildiği 1917-1923 yıllarıdır. Bu dönem militarist yaklaşımla yeni kurulmuş devletin pozisyonunu savunanları ve askerlerin beden eğitimi yardımıyla muhakkak hazır olmalarını talep ediyordu. Tüm askeri sahada atıcılık ve jimnastik cemiyetlerinin bölge komiserlikleri, eyaletler, il ve ilçelerde organize edilmesi ve aynı şekilde emekçi halkın genel askeri eğitimlerinin yürürlüğe alınması ile alakalı halk komiserleri kurulu kararnamesi 8 Nisan 1918'de kabul edilmiştir. Bu kararnamenin alınış amacı; halkı genç devletin savunmasına hazırlamaktır. Spor ve beden eğitimi sahasında kadroların yetiştirilmesi için yukarda da belirttiğimiz gibi daha ilk yıllarda Petersburg ve Moskova'da beden eğitimi ve spor yüksekokulları kurulmuştur. Ülkedeki kıtlığa, işsizliğin artışı ve üretimin düşmesine bağlı olarak oluşan olağan dişı şartlara rağmen devletin ve toplumun yapısını şekillendirmek için spor ve beden eğitimi sahasında ülke topraklarının hatırı sayılır kısmında etkin bir süreç devam etmiştir.

$\mathrm{Bu}$ sürecin şekillenmesinde ana rolü, genel askeri eğitimin ana idaresi oynuyordu. ${ }^{12}$ Sovyetler Birliği Komünist Partisinin ve Sovyet idaresinin, beden eğitimi ve spora ilgisi, iç savaşa ve yabancı müdahalelerine karşı olan, mücadele sürecinde olmuştur. ${ }^{13} \mathrm{Bu}$ süreçte askeri eğitim devlet yapılarının ilki olmuş ve onun da katılımı ile yerli spor yeniden hayat bulmuştur. Beden eğitimi ve sporun pratiği olimpiyatlar ile temellendirilirken bölgesel olimpiyat

12 V.N. Zuyev, N.V. Astafyev, "Sportivnoe Pravo v Strategii Upravleniya Sferi Fiziçeskoy Kulturı i Sporta Sovetskovo Perioda", Vestnik Yomskovo Gasudarstvennovo Universiteta, No:3, 2012, s. 238

${ }^{13}$ N.N. Burgov, Fiziçeskaya Kultura i Sport v SSSR i Zarubejnih Stran, Moskva, 1979, s. 7 
komiteleri kurulmuş, spor toplulukları yeniden kurulurken uluslararası olimpiyat komitesi ile sadece ilişki kurma girişimiyle yetinilmemiş, sıradaki Belçika'daki olimpiyatlara da katılmaya çalışılmıştır. Tüm bu eğitim organizasyonlarında yaklaşık 17 bin eski çarlık ordusu subayı görev almıştır. Merkezde olduğu gibi eyaletlerde de Rus sporunun oluşumuna ve onun hukuki temellerinin şekillenmesine yardım etmişlerdir.

\section{İkinci Etap: Yeni İş Kollarının Oluşturulmasında ve Düzenlenmesinde Spor (1923-1950)}

$\mathrm{Bu}$ dönem 1923-1950'li yıllar arasındaki “devlet idare organlarının yeni iş kollarının oluşturma ve düzenlemesi" sürecidir. Rus devletinin tüm tarihi boyunca ilk kez federal düzeyde iş kolu olarak bağımsız idare organı olmuştur. 27 Haziran 1923 yılında Tüm Rusya Merkezi Yönetim Komitesi "Rusya Federasyonu emekçilerinin yerel ve yüksek seviyede beden eğitimi kurullarının kurulması" ile ilgili kararnameyi kabul etmiştir. Emekçilerin beden eğitimi sahasında örgütsel eğitim ve metot birliklerinde kararnamelerin içerisine stratejik yönetimler konulmuştur. Adı geçen yönetim organları 1936 yılına kadar halkın beden eğitimi gelişiminin istikametini belirlemişlerdir. ${ }^{14}$ Partinin beden eğitimi sahasındaki vazifeleri hakkındaki parti merkez komitesinin kararnamesi beden eğitimi için kalıcı bir değere sahiptir. 1925 yılında alınan bu karar sosyalist yolda gelişen beden eğitiminin sağlam metodolojik temeli olmuştur. Ad1 geçen kararnamede Sovyet toplum şartlarında beden eğitimi gelişiminin temel yönleri şartlara bağlanmıştır. Böylelikle kitlesel köylü yığınları arasında sporun gelişiminin gerekliliği hakkındaki sorunda ortaya konulmuştur. Yaygın kültüre beden eğitimi üzerinden köylülerin kazandırılması konusunda partinin niyeti tam olarak ortaya çıkmıştır. Bu şekilde daha Sovyet iktidarının ilk yıllarında şehir ve köy arasındaki karşıtlıklar ve farklılıkların yumuşatılmasına yönelik tedbirler alınmaya başlanmıştır. Bunun yanı sıra kararnameye milli cumhuriyetlerin yerli halkları arasında spor ve beden eğitiminin gelişimi ile alakalı konuda dâhil edilmiştir. Bu yönergenin hayata geçirilmesinde amaç sosyalist kültürün işlemesine ve milli kültürlerinde yakınlaşmasına yardımcı olmaktır. ${ }^{15}$

${ }^{14}$ В.Н. Зуев, Н.В. Астафьев, “Спортивное право в стратегии управления сферы физической культуры и спорта советского периода" Спортивное право в стратегии управления, 2012 s. 238

${ }^{15}$ N.N. Burgov, a.g.m., s. 7-8 
21 Haziran 1936 yılında Halk Komiserleri Kurulu kararı ile SSCB Halk Komiserliği Kurulunda tüm birlik cumhuriyetleri beden eğitimi ve spor kurulunun kurulması ile alakalı karar alınmıştır. Arkasından parti ve kurul organlarının da yardımıyla, uygulamalı yönü de mevcut olan sportif düzenlemeler kompleksi olan "GTO”lar hayata (GTO/ГTO)* geçirilmiştir. Hali hazırda tek bir düzenleyici yasal yapının olmasından dolayı stratejik yönetimin de rolü güçleniyordu. GTO spor komplekslerinin temelinde birleşik spor sınıflandırması şekilleniyordu. Bu dönemde spora özendirmek için sportif kategori ve unvanlar da ortaya çıkmaya başlamıştır. 1935 yılında ortaya çıkan “emektar spor ustası" ve 1936 da ki "SSCB spor ustası" bunlardan bir kaçıdır.

1936 SSCB anayasasında sportif topluluklar ve farklı toplumsal organizasyonlarda hak ve hukukları düzenlenirken 1935-1936 yılları arasında SSCB de gönüllü spor toplulukları (organizasyonun Rusça orijinal isminin kısaltması ДСО = DSO) oluşturulmuştur. 16 "Kızıl Bayrak", "Lokomotif",

* GTO: Ülke halkının erken yaşlardan emeğe ve savunmaya hazırlanması.

16 DSO (ДСО добровольных спортивных обществ) - Her ne kadar yönetimi devlet karakteri taşısa da SSCB de kitlesel spor ve beden eğitiminin gelişiminde gönüllü spor topluluklarının faaliyetleri kilit rol oynadı. Gönüllü spor toplulukları birlik cumhuriyetlerinde bölgesel ya da il, ilçe, fabrika, işletme yada eğitim kurumlarının spor kolektiflerinin birleştirilmesi ile kuruldular. Gönüllü spor topluluklarının faaliyetleri özerklik prensibi temelinde kurumların tüzüğü ile uygun olarak belirlendi. 1936-1938 yıllarında sendikalar bünyesinde oluşturulan gönüllü spor topluluklarını sanat ve endüstri meslek okulları sporcuları 1946 yılında "emek rezervleri” topluluğuna dâhil edildi ve 1950'li yıllarda birlik cumhuriyetlerinde köy gönüllü spor kurumları organize edildi. 1971 yılı itibariyle SSCB de 36 gönüllü spor topluluğu faaliyet gösteriyordu. Bunlardan isimleri "Burevestna", "Vodnik", "Zenit", "Lokomotif", "Spartak" ve "Trudovie Rezervi" olan içlerinden altı tanesi tüm Sovyetler Birliğini kapsayacak şekilde faaliyet gösteriyordu, 15 tanesi ise cumhuriyetler ölçeğinde sanayi kuruluşlarının birleşik beden eğitimi kolektifleriydi. 1 Ocak 1970 yılı itibariyle 114 bin öncü temel gönüllü spor topluluğu organizasyonu faaliyet göstermekteydi, bunlardan 105 bini sendikaldi (25 milyon sporcu). Gönüllü spor toplulukları bünyesinde 1350 çocuk-genç klasmanında spor okulu, bir çok spor kulübü ve 50 bin antrenör faaliyet gösteriyordu. 1946-1970 y1lları arasında gönüllü spor toplulukları bünyesinde 60 binden fazla spor uzmanı yaklaşı olarak 2 bin emektar spor uzmanı yetiştirildi. Gönüllü spor toplulukları tüm bu faaliyetlerini sendikal organizasyon, kurum ve köy kolektifleri ile birlikte yürüttü. İnsan faktörünün yanında spor komplekslerinin de inşası da bu süreç zarfinda hayata geçirilmiştir. 1970 yılı itibariyle gönüllü spor toplulukları bünyesinde 2490 stadyum, 59 bin futbol sahası, 14,4 yüz spor sahası kompleksi, 10,2 yüz jimnastik salonu, 950 havuz ve sportif oyunlar için yaklaşık 270 bin spor alanı vardı. Gönüllü spor 
"Spartak", "Dinamo" gibi takımların tecrübeleri, beden eğitimi ve spor alanının kooperatif eğiliminin gelişimine ve iyileşmesine yardımcı olacağı düşünülerek her zaman gözler önünde tutulmuştur. İkinci dünya savaşının başlaması ile birlikte savaş şartlarından ötürü tüm ülke güçleri seferber edilmiştir. 25 Haziran 1941 yılında Sovyetler Birliği Halklar Komiserliği kurulunda spor komitesi tüm sportif organizasyonların askeri eğitimlerde çalışmalarına yönelik kararnameyi yayınlamıştır. Temmuz 1941 yılı itibari ile aynı zamanda birlik cumhuriyetlerinden biri olan Rusya Sovyet Sosyalist Cumhuriyeti Eğitim Bakanlığı Yüksekokul, kolej ve üniversitelerin eğitim programına fiziki askeri eğitim koymuştur.

Savaştan sonraki dönemde devlet, beden eğitimi ve spor kolunun yardımı ile ulusal ekonomiyi yeniden canlandırmayı planlamıştır. 23 Eylül 1945 yılında halk komiserleri kurulu beden eğitimi ve spor komitesine yardım edilmesi ve çalışmalarının iyileştirilmesine yönelik kararnameyi kabul etmiştir. 2 Temmuz 1947 yılında Sovyet Bakanlar Kurulu sportif faaliyetlerin özendirilmesi için "Sovyet sporcuların sportif başarılarının artışını özendirmek" ve " Sovyet sporcularını başarılarından ötürü ödüllendirilmesi” için jeton ve madalyalar üretilmesine yönelik kararnameler kabul etmiştir.

\section{Üçüncü Etap: Uluslararası Arena ve Kitlesel Spor (1950-1991)}

$\mathrm{Bu}$ dönem, sportif becerinin geliştirilip uluslararası arenaya çıkış ve kitlesel sporun gelişim dönemidir. Spor ve beden eğitimi sahasında komite tarafından icra edilen süreç ile ilgili ve 1952 yılında Helsinki'deki olimpiyat yaz oyunları ve ülke içerisinde Sovyet sporcuların artırılması ve kitlesel beden

topluluklarının çalışmalarına kaynak sendika bütçelerinden aktarılıyordu. (1970 335 milyon ruble) her topluluğun bayrağı, amblemi, takım forması ve rozeti vardı. Tüm Sovyetler Birliği gönüllü spor toplulukları sendikaları kurulu yönetici konumundaydı. Aynı kurul sportif bayramların, SSCB sendikalar Spartakiadanın ve spor kurumları arasındaki yarışmaların organizatörlüğünü, gönüllü spor topluluklarının tüm Sovyetler Birliği ve uluslararası arenada şampiyonalara katılımını sağlamanın yanı sıra genç ve çocuk spor okullarının faaliyetleri, beden eğitimi kadrolarının niteliklerinin kontrol ve yükseltilmesi işlerini de idare ediyordu. Spor komplekslerinin inşasının yanı sıra uluslararası öğrenci ve işçi birlikleriyle de işbirliğini geliştiriyordu. Kurulun yanında spor federasyonları, antrenör kurulları ve hakem heyetleri mevcuttu. Kurulun ekonomik giderleri bütçeden ve gönüllü spor toplulukları üyesi olan vatandaşlar tarafindan yapılan ödeme ile karşılanıyordu. Gönüllü spor topluluklarının aktif faaliyetlerine 1980'li yıllarda son verilerek mal varlıkları sendikal organizasyonlara aktarıldı. 
eğitiminin gelişimine yönelik düzenlemeler yapılmıştır. 27 Şubat 1947'den itibaren komünist parti merkezi komitesinin kararnamesi yeni normatif hukuki düzenlemelerin benimsenmesi ve uygulanması sürecini açmıştır.

SSCB olimpiyat komitesinin kuruluşundan sonra (07.05.1951) tüm Rusya birleşik spor sınıflandırma sisteminin talebi doğrultusunda kış (1956'dan) ve yaz (1952'den) olimpiyat oyunlarındaki sonuçlar temel manada incelenmeye başlanmıştır. 22 Ocak 1956 yılında 1956 yazı itibari ile SSCB halklarının birinci Spartakiadası'nın ${ }^{17}$ organize edilmesine yönelik SSCB bakanlar kurulu karar almıştır. Bununla okul öğrencilerinin, spor sendikalarının, geçit törenlerinin, spor bayramlarının, birlik cumhuriyetlerinin spartakiada tecrübesinden istifade edilmek istenmiştir. Bu süreçte öncelikle kitlesel beden eğitimi sahasında ve önemli görülen spor türleri alanında dünya birincilikleri ve spor uzmanlığının gelişmesi amaçlanmıştır. Tüm bu sürecin elde edilmesi ve devam ettirilebilmesi şüphesiz ki beraberinde ciddi bir ekonomik külfeti getirmiştir. ${ }^{18}$

I. SSCB Halkları Spartakiadası'nın önemi spor işleri ve beden eğitiminin bir nevi kontrolü, denetlemesi olmasındadır. Bu spartakiada geniş halk yığınlarının düzenli beden eğitimi ve sporla ilgilenmesine yardımcı olmuştur. Spor türlerinin gelişimi ve sportif başarıların artışı özendirilirken, karma takımlar ile katılmış kabiliyetli sporcularında ortaya çıkmasına

${ }^{17}$ Spartakiada (спартакиада) Romalı kölelerin isyanında lider konumunda olan Spartaküs'ün adına ithafen Spartakiada olarak adlandırılan spor organizasyonu geçtiğimiz yirminci yüzyılın ilk yıllarında organize edilmeye başlandı. Spartakiada SSCB'nin boykot edilmesi sebebi ile katılamadığı 1920'li yıllarda olimpiyatların yerini doldurması düşüncesi ile yaygınlaşmaya başladı. 1920 yılında organize edilen VII. Olimpiyatlara Sovyetler Birliği kendisine uygulanan boykotun spor sahasında taşınması ile katılamadı. Bu hadise sonrasında SSCB sporcuları bir sonraki sefer 1952 yilında Helsinki'deki olimpiyatlara katılabildi. Tüm birlik cumhuriyetlerini de kapsayacak şekilde ilk Spartakiada 1928 yllında Moskova'da gerçekleştirildi. Organizasyona 7 bin kişi ve 600 de yabancı sporcunun katılımı ile yarışmalar uluslararası nitelik kazandı. Arkasından 1932 yılında uluslararası spartakiada organize edilmesiyle sonraki yıllarda silahlı kuvvetler, SSCB halkları, sendikalar, spor kulüpleri "Spartak" ve "Dinamo" nun Spartakiadaları yapıldı. SSCB'nin ilk yıllarında tüm Rusya'yı kapsayacak şekilde öğrenci ve izciler spartakiadası organize edildikten sonra uzun bir ara ile tüm birlik cumhuriyetlerini de kapsayacak şekilde 1954 ten sonra her yıl öğrenci spartakiadaları organize edilmeye başlandı. Günümüzde de spartakiada geleneği birçok spor kulübü, öğrenci kolektifleri ve benzeri sportif topluluklar arasinda devam ettirilmektedir.

${ }^{18}$ B.Н. Зуев, Н.В. Астафьев, s. 238 
yardımcı olmuştur. 1959 yılında SSCB Halkları Spartakiadası'nın ikincisi organize edilmiştir. Bunu diğerinden farklı kılan özelliği cumhuriyet karma takımlarının yanında beş farklı spor alanında kurumların, fabrikaların ve işletmelerin beden eğitimi kolektiflerinin takımlarının da katılmasıdır. Yüzme ve atletizmde en iyi sonuçları Leningrad mekanik-optik fabrikasının sporcuları, jimnastikte Moskova'nın "Fili” kulübü, bisiklette ise Rijsk vagon tamir fabrikası ve diğer kolektifler elde etmiştir. ${ }^{19}$

1950'li yılların sonu 1960'lı yılların başında ülke ekonomisi ve politik durumunda ciddi düzenlemeler yapılmıştır. Aynı netleştirmeler beden eğitiminin sonraki gelişimi içinde yapılmıştır. 1959 yılı başında toplanan Komünist Partisi XXI. Olağanüstü kongresinde sosyalizmin SSCB'de bütün ve nihai zafer kazandığını ve ülkenin komünizmin detaylı kuruluş sürecine girdiği ilan edilmiştir. $\mathrm{Bu}$ fikrin mantıklı temeller üzerine oturtulması komünist partinin Ekim 1961 deki XXII. Kongresinde komünist partinin yeni programı ile olmuştur. Adı geçen program komünist toplumun inşası için birbiri ile ilişkili şu üç temel hedefi belirlemiştir;

1.Komünizmin maddi teknik temelinin kurulmas1;

2.Komünist toplumsal ilişkilerin oluşturulması;

3.Fiziksel yetkinliği, ahlaki temizliği ve ruhsal zenginliği kendisinde uyumlu bir şekilde birleştiren yeni insanın eğitimi.

Tüm bu üç önemli vazifenin pratikte hayata geçirilmesinde en önemli rol beden eğitimi ve spor kurumlarına verilmiştir. ${ }^{20}$

1966 yılı itibariyle beden eğitimi gelişiminin yedi yıllık planı özetlendiğinde, komünist parti merkez komitesi ve SSCB Bakanlar Kurulu 1959-1965 yılları arasındaki dünya çapında spor faaliyetlerine geçiş etabının tecrübesini analiz ederken kitlesel artış, yaratıcı inisiyatifin gelişimi ve sporcuların girişkenlikteki başarıları da ifade edilmiştir. Bunun yanında şu sonuçlara ulaşılmıştır; 1959 yılında kurulan toplumsal spor faaliyetleri yönetim organı, belirlenen hedefleri tam manası ile hayata geçirebilmek için gerekli yetkiye sahip değildir. Bu eksikliklerin üstesinden gelebilmek için beden eğitimi sahasında devlet idaresinin artırılması yönünde karar alınmıştır. Ağustos 1966 'da alınan kararda da gösterildiği üzere beden eğitimi faaliyetleri bilimsel temel üzerine kurulmalıydı. Bununla birlikte eğitim gören gençlerin

\footnotetext{
${ }^{19}$ V.K. Pelmenev, Ye.V. Koniyev, İstoriya Fiziçeskoy Kulturı, Kaliningrad, 2000, s. 129

${ }^{20} \mathrm{http}: / /$ studopedia.info/1-93024.html
} 
beden eğitimlerinin köklü şekilde iyileştirilmesine özel bir alaka gösteriliyordu. Beden eğitimi kadrolarının eğitim sistemlerinin iyileştirilmesi, bilimsel karma alanların hazırlanması ve hayata geçirilmesi, farklı alanlarda bilimsel okulların oluşturulması ve yerli bilim insanlarının uluslararası arenaya çıkmasına yönelik bir dizi adım atılmaya başlanmıştır. Bilimsel çalışmaların ana eğilimi kitlesel beden eğitimi ve sporun yüksek başarısını örgütsel, metodik ve teorik olarak hazırlamak olmuştur. ${ }^{21}$

1977 yılında SSCB'nin yeni anayasası kabul edilmiştir. Yeni anayasada çalışanların ve genç neslin ruh ve beden gelişimine ciddi dikkat gösterildiği “toplumsal gelişme ve kültür” diye bir bölüm konulmuştur. 1 Mart 1972 den itibaren yeni GTO kompleksleri kurulmaya başlanmıştır. 1959 yılının kompleksleri yeni hedeflere uygun olmadığı gibi beden eğitimi sisteminin ileriki olgunlaşma ilkesine hizmet edemezdi. Bu kompleksler kitlesel beden eğitiminin tüm halk seviyesinde hedeflenen dönüşümü hayata geçirebilmesi için geniş imkânlar sunmak zorundaydı. Kompleks 07-60 yaş aralığını kapsayacak şekilde 6 basamaktan oluşuyordu:

I. Basamak "başlangıca hazırlık" (7-9 yaş arası çocuklar için)

II.Basamak "cesur ve becerikliler" (10-13 yaş arası kızlar ve erkekler için)

III.Basamak "sportif değişim" (14-15 yaş arası ergenler için)

IV.Basamak "güç ve cesaret" (16-18 yaş arası genç kız ve erkekler)

V.Basamak "fiziki yetkinlik" (19-39 yaş arası erkekler, 19-34 yaş aras1 kadınlar)

VI.Basamak "dinçlik ve sağlı"” (40-60 yaş arası erkekler, 35-55 yaş arası kadınlar)

Beden eğitimi ve sporun toplumun tüm hayatına girmesi fikri, Sovyetler Birliği Komünist Parti Merkezi Komitesi ve SSCB Bakanlar Kurulunu Eylül 1981 de "spor ve kitlesel beden eğitiminin ileriki geliş̧imine yönelik" kararlar almaya itmiştir. Adı geçen kararnamede, beden eğitimi faaliyeti yeni şartlarda geniş bir programa sahip olurken program beden eğitiminin birçok önemli sorununu da kapsiyordu. Beden eğitimi komitesine, yaşam mahallerinde sportif kulüpler ağının genişletilmesi, eğitim kurumlarının programlarının

\footnotetext{
${ }^{21} \mathrm{http}: / /$ studopedia.info/1-93024.html
} 
incelenmesi, sağlığa yönelik spor kamplarının çalışmalarının iyileştirilmesi ve bilimsel çalışmaların desteklenmesi önerilmiştir. ${ }^{22}$

\section{Moskova Olimpiyatları}

1980 yılının ikinci yarısı itibariyle SSCB'nin hayatında en önemli hadise 1980 Moskova olimpiyatıdır. 1980 olimpiyatı SSCB için tüm tarihi boyunca bu ölçekteki en büyük olaydı; uzun yılların hazırlığı kitlesel basının dikkati, binlerce ziyaretçi, benzeri olmayan dramatizm tüm bunlar Moskova olimpiyatını muazzam olaylar kategorisine taşıyordu. Bu sebeple geç Sovyet periyodu ve soğuk savaş bağlamında büyük sportif hadiselerin hazırlık niteliğini incelemek önemli amaçtır. Hiç şüphesiz 1971 y1lında Sovyetlerin olimpiyat komitesine ilettiği talebin ilk anından beri Moskova olimpiyatının en önemli sebeplerinden biri de ideolojikti. Olimpiyatın kendisi sadece sosyalist bloğun içerisinde değil, kapitalist ülkelerde de Sovyet yaşam tarzı ve ideolojisinin anlatılabileceği bir propaganda olarak planlanıyordu. Bunlardan başka Sovyetlerin uzay bilgisi, gelişmekte olan ülkelere yardım gibi politik olmayan ünlü konularda Sovyet başarılarının gösterileceği genel şemaya dâhil edildi. Böylesine olimpiyat gibi büyük ölçekli sportif bir faaliyet içeride vatanperver ruhu yükseltirken, Sovyetlerin uluslararası imajını da iyileştirecekti. ${ }^{23}$

25 Kasım 1979 yılında Sovyet Ordusunun Afganistan'a girişine bir cevap olarak 20 Ocak 1980 yılında Amerika başkanı Jimmy Carter Moskova'daki oyunları boykot ettiklerini bildirirken diğer ülkeleri de bu boykota katılmaya davet etmiştir. Bu boykota Amerika'nın yanında Batı Almanya ve Japonya katılmıştır. 1980 Moskova Olimpiyatına Batı ülkelerinin temsilcilerinin katılmaması demek Moskova Olimpiyatını ikinci derece önemli bir organizasyon durumuna düşürecekti. Fakat SSCB Moskova Olimpiyatının başlamasına üç gün kala olimpiyat komitesi başkanı seçilen Huan Antonio Samaranç'ı kendi tarafina çekmeyi başarmıştır. Çok kısa süre zarfinda Samaranç İspanya, İtalya, İngiltere ve bir kısım ülkeyi temsil eden sporcularını Moskova'ya gönderme konusunda ikna edebilmiştir. Birçok batılı

22 В.К. Пельменев, Е.В. Конеева, История физической культуры: Учебное пособие, Калининград , 2000, s. 134,135

23 Olga Çepurnaya, "Olimpiyada-80": Savetskoe Megasabıtie v Kontekstah “Holodnoy Voynı”, 2004, s. 40-43 
devletin katılmamasına rağmen Moskova Olimpiyatı SSCB için birçok spor alanında ciddi dünya rekorları kırılarak tamamlanmıştır. ${ }^{24}$

Sovyetler Birliği Aralık 1991 de dağılana kadar ve sonrasında, birliği oluşturan bağımsız devletlerde Sovyet spor kültürü ve tesis edilen spor alt yapısı devam edip gelmiştir. Hali hazırda hem Rusya hem de Sovyetleri oluşturan diğer birlik cumhuriyetleri yeni dünya ya entegre olma sürecinde, modern dünyanın tecrübesinden istifade etmeye çalışırken bunu Sovyetlerden kalan bilgi ve alt yapısıyla beraber sürdürmektedir.

\section{Sonuç}

Toplumsal yaşamı daha sağlıklı kılmak, iyi nesiller yetiştirmek ve ulus bilinci yerleştirmek için sporun çok önemli rolü ${ }^{25}$ olduğu düşüncesi, Sovyet toplumlarının kuruluş döneminde komünist fikirlerin oturtulmasında önemli bir paradigma olarak karşımıza çıkmaktadır. 20. Yüzyılda spor toplum hayatında ciddi etki gösteren kitlesel bir fenomene dönüşürken, gerek içeride gerekse uluslararası boyutta milletlerin iletişimini sağlayan istisnai soysokültürel bir çizgiye de ulaşmıştır. Birçok alanda modern Rus toplumunun gelişimi önceki tarihsel gelişimin mirası ile anlam bulmaktayken, Rus sporunun bugünkü durumu da aynı şekilde Sovyet döneminde ve temelde onun eğilim ve niteliklerinde şekillenmiştir.

Çarlık Rusya'sında sadece belirli bir sosyal sınıfın meşgul olabildiği ve dar bir çevreye sıkışmış olan sporun, Sovyetler için tamamen farklı bir işleve sahip olduğu gözlenmektedir. Sovyetler Birliğinde sporun gelişimi ve onun toplumu şekillendirmesindeki rolüne baktığımızda, ilk olarak komünist düşünce perspektifinde, beden eğitimi ve spordan faydalanılarak tüm askeri eğitimle ilgili stratejik kararların alındığını söylemek mümkündür. Tüm insanlığın aydınlık geleceği için yenilmez ruhla savaşacak savaşçların ve komünizmi inşa edecek yeni nesillerin yetiştirilmesinde kitlesel beden eğitimi ve spor en iyi araç olarak görülmüş ve kullanılmıştır.

İkinci olarak, toplumsal yapıyı şekillendirmek ve mevcut sistemi yaygınlaştırmak için, devlet organlarının yeni iş kolları oluşturma ve

\footnotetext{
${ }^{24} \mathrm{http}: / /$ olimp-history.ru/node/350

${ }^{25}$ Metin Kılıç, Tek Partili Dönemde Türkiye'de Modern Sporun Teşekkülü. Tarih Okulu Dergisi, 2013,(XIV). s. 1.; Metin Kılıç, Etnisite ve Spor, Doğu Kütüphanesi Yayınları, İstanbul, 2012, s.86.
} 
geliştirme sürecini düzenlediği görülmektedir. 1923'ten 1950'li yıllara kadar süren bu süreçte düzenlenen kararnamelerle DSO adı verilen gönüllü spor topluluklarının birleşmesi ve yaygınlaştırılması söz konusudur. Spor alanlarının ve dallarının yaygınlaşmasına imkân sağlayan bu dönemde sosyalist yönde gelişen beden eğitimi ve sporun sağlam metodolojik temellerinin atıldığı ve spor sayesinde Sovyet iktidarının köy ve şehir hayatı arasındaki karşıtlıkların ve farklılıkların yumuşatılmasına yönelik tedbirler aldığı görülmektedir.

Son olarak 1950'li yıllardan Sovyetlerin dağılmasına kadar incelediğimiz ve bugünkü Rus toplumunun devam ettirmeye çalıştığı sportif becerinin geliştirilmesi ile uluslararası arenaya çıkış ve kitlesel sporun yaygınlaştırılması sürecidir. Sovyet toplumlarının bu sürece girmesinde kuşkusuz olimpiyat oyunlarında boykot edilmesinin ve geçmiş olimpiyatlara katılmamasının etkisi büyüktür. 1951 yılında kurulan SSCB olimpiyat komitesinin çalışmaları neticesinde, kitlesel beden eğitimi sahasında ve önemli görülen spor branşlarında dünya birincilikleri ve spor uzmanlığının gelişmesi amacıyla ilki 1928 yılında yapılan spartakiada spor organizasyonlarının yeniden düzenlenmesi yasallaşmıştır. Bununla okul öğrencilerinin, spor sendikalarının, geçit törenlerinin, spor bayramlarının, birlik cumhuriyetlerinin spartakiada tecrübesinden istifade edilmek istenmiştir. Kitlesel anlamda bütünleşmeyi sağlayan bu spor organizasyonuna günümüzde de Rusya' da devam edilmektedir.

İlk dönemden son döneme kadar Sovyet toplumunda sporun siyasal ve hukuksal düzenlemelere bağlı olarak toplumu şekillendirdiği söylenebilir. Bu şekillendirme kuşkusuz 1980 Moskova olimpiyatlarında kırılan dünya rekorlarıyla ve birçok alanda kazanılan madalyalarla başarısını tamamlamıştır. Birçok batı ülkesinin soğuk savaş döneminde boykot ettiği ve katılmadığı Moskova olimpiyatlarının önemi kuşkusuz ideolojik temellere dayandırılmasıdır. Sovyetlerin uluslararası imajını düzeltmek ve ideolojisini anlatabilmek adına iyi bir firsat olarak görülen bu olimpiyatlara dünyanın ilgisi çok fazla olmuş ve etkileri bugün bile tartışma konusudur.

\section{KAYNAKÇA}

Bliznevskiy, Y.A. (2015). Programmo-Tselevoe Upravlenie Razvitiem SferiFiziçeskoy Kulturı i Sporta v Prostranstve Krasnoyarskovo Kraya. Yayınlanmamış Doktora Tezi, Krasnoyarsk. 
Burgov, N.N. (1979) Fiziçeskaya Kultura i Sport v SSSR i Zarubejnih Stran, Moskva,

Buton, V.S. (2007). Razvitiye Sovetskovo Futbola (1921-1941). Yayınlanmamış Yüksek Lisans Tezi, Krosnoyarsk.

Çepurnaya, O. (2004). Olimpiyada-80: Savetskoe Megasabitie v Kontekstah. Holodnoy Voynt, 2004(40-43).

Filippov, N.A. (2012). Gasudarstvennaya Politika SSSR v Oblast1 Fiziçeskoy Kulturı i Sporta: 1920-1930. Yayınlanmamış Yüksek Lisans Tezi, Yaroslavl.

Kalomnikova, T.; Varonin, A. (2013). Sotsialnaya Rol Sporta v Razvitii Obşestva i Sotsializatsii Liçnosti. Uspehi Savromennovo Estestvaznaniya, 2013(10).

Kılıç, M. (2012). Etnisite ve Spor. Doğu Kütüphanesi Yayınları, İstanbul.

Kılıç, M. (2013). Tek Partili Dönemde Türkiye'de Modern Sporun Teşekkülü. Tarih Okulu Dergisi, 2013(XIV).

Niva, T. (1979). Funktsiya Sporta v Sovremennom Obşestve. Sport $i$ Obraz Jizni. Sbornik Statey, Moskva.

Pelmenev, K.V.; Koniyev, V.Y. (2000). İstoriya Fiziçeskoy Kulturı. Kaliningrad.

Ratuşnaya, Y.Y.; Mihaylov, İ.Y. (2012). Organı Upravleniya Fiziçeskoy Kulturoy i Sportom v 1991-2007. (Regionalniy Aspekt). Vestnik $\mathrm{KemGU}, 2012(3 / 51)$.

Salovyev, V.P. (2007). Fiziçeskaya Kultura i Sport v Sotsyokulturnom Razvitii Sibirskovo Goroda Tomska: 1920-1941. Yayınlanmamış Yüksek Lisans Tezi, Krasnoyarsk,

Yu.A, S. (2004). Konseptsiya Sporta Kak Politika i Yiyo Realizatsiya Na Stranah SMI. Gumanitarnie Nauçnie İsledovaniya, 2004(2).

Zuyev, N.V.; Astafyev, V.N. (2012). Sportivnoe Pravo v Strategii Upravleniya Sferi Fiziçeskoy Kulturı i Sporta Sovetskovo Perioda. Vestnik Yomskovo Gasudarstvennovo Universiteta, 2012(3).

Зуев, Н.В.; Астафьев, В.Н. (2012). Спортивное право в стратегии управления сферы физической культуры и спорта советского периода. Спортивное право в стратегии управления, 2012(237-241).

Пельменев, К.В.; Конеева, В.Е. (2000). История физической культуры: Учебное пособие, Калининград. 
http://minsport.gov.ru/ İstoriya Razvitiya Fizkulturı i Sporta Sredi Selskovo Naseleniya v SSCB i Rassıskoy Federatsii.

http://olimp-history.ru/node/350

http://studopedia.info/1-93024.html

http://studopedia.info/1-93024.html

\section{RESIMMLER}

Resim 1. Tarlada işçiler çalışmaya başlamadan önce sabah jimnastiği yapıyor

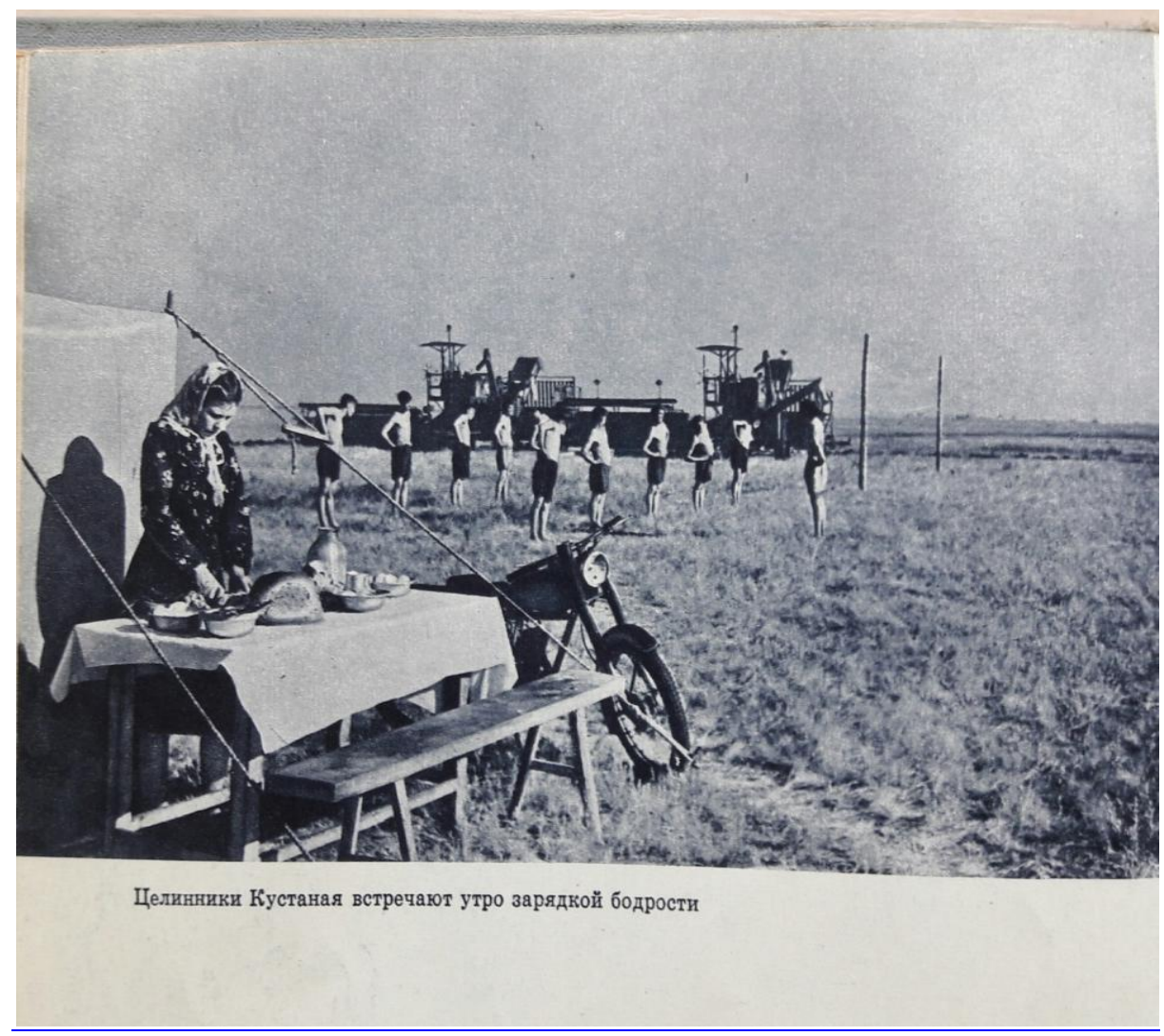




$$
\text { Metin Kılıç - Mahir Aslan }
$$

\section{Resim 2. Köylüler Voleybol Oynuyorlar}

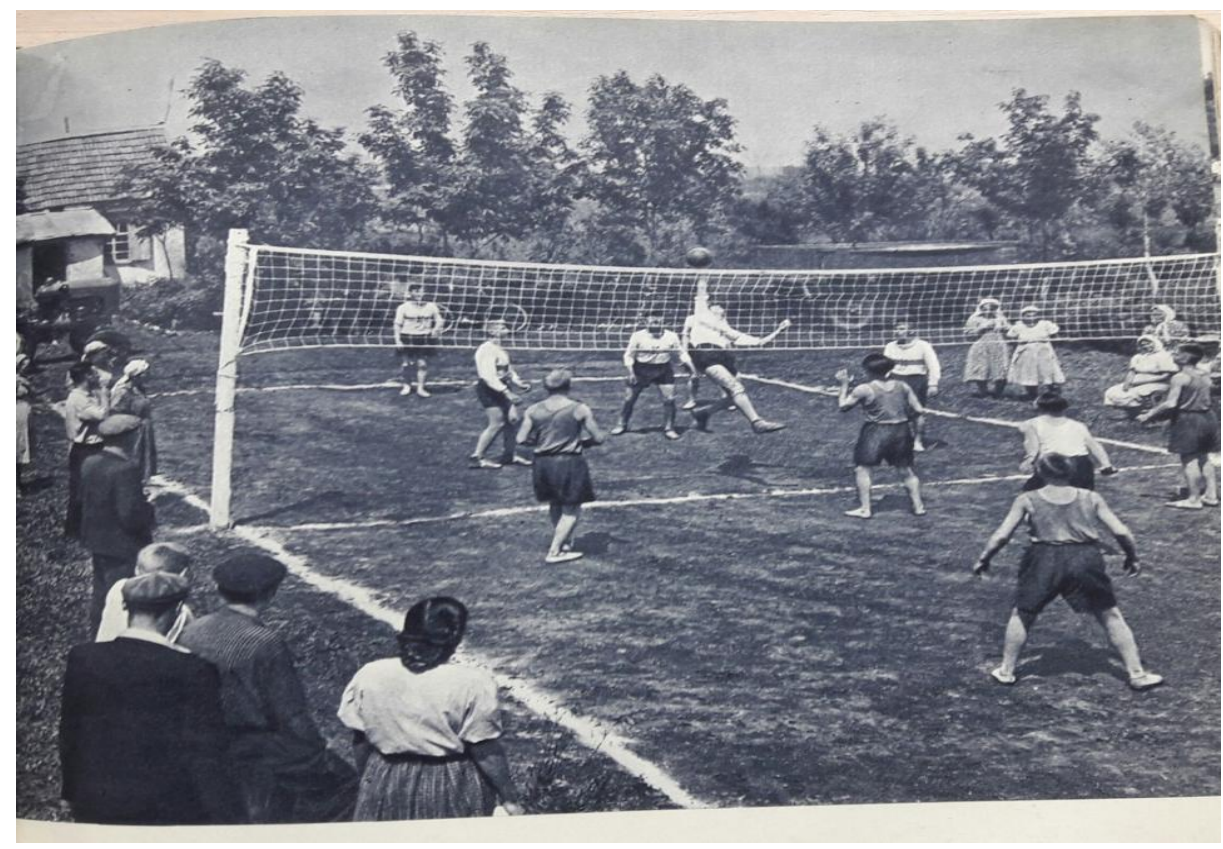


Sovyet Toplumunda Sporun Rolü

Resim 3. Fabrika İşçileri Ara verip Egzersiz Yapıyorlar

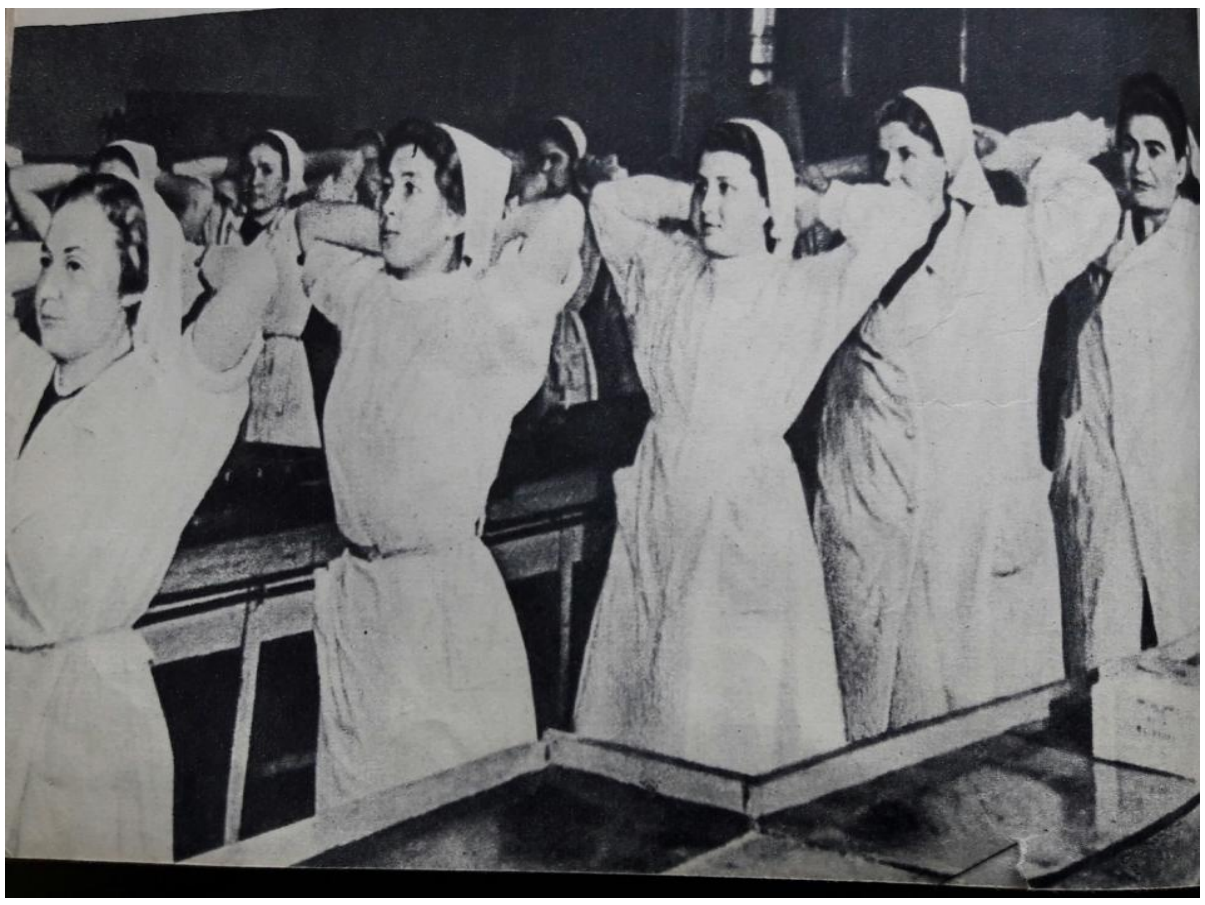

